\title{
Doubling Farmers Income through Gender Specific Interventions
}

\author{
J. Charles Jeeva*, S. K. Srivastava, Anil Kumar, Sabita Mishra, A. K. Panda, \\ Jyoti Nayak, S. Tanuja, Ankita Sahu, B. C. Behera, M. Prusty and Subrat Kr. Das \\ ICAR-Central Institute for Women in Agriculture, Bhubaneswar-751 003, Odisha, India \\ *Corresponding author
}

\section{A B S T R A C T}

The study was taken up with the objectives of profiling income generating activities of farm families and identifying points of interventions; conducting micro level studies to

\section{Keywords}

Doubling farmers income, Gender mainstreaming, Technological interventions, Extension strategies and Impact assessment

\section{Article Info}

Accepted: 14 June 2020 Available Online: 10 July 2020 identify gender concerns and technological gaps in doubling farm income; implementing technological modules for enhancing productivity with an aim to enhance farm income with emphasis on integrating gender roles and to study the impact of the interventions to develop a gender-sensitive model for doubling farmers' income. The study was taken up in a cluster of 50 farm women from selected villages in Nimapara block of Puri district in Odisha during 2017-2020. A gender sensitive model to enhance farmers' income by addressing gender concerns and technological gaps was developed. The gender perspectives were integrated by way of assessment of gender concerns in accessing productive resources and extension services among the farm families, counselling and gender sensitization of the community, and promoting community organizations such as knowledge groups of men and women. Team of experts analyzed the technological and developmental gaps and designed need based technological modules. The need based modules were implemented through training, demonstrations, capacity building programmes, input support and advisory services, and promoting high yielding varieties and hybrids. The impact of the field level capacity building and technology transfer programmes could be realized in terms of enhancement of annual farm income from Rs. $89,300 /$ - to Rs. $1,51,200 /-$ (69\% enhancement), and cash in hand among farm women (mean annual savings) from Rs. 18,000/- to Rs. 42,000/- (113\% enhancement) between 2017-18 to 2019-20. The focus area and the extension strategies for gender mainstreaming and improving livelihood are also discussed in this paper.

\section{Introduction}

Aiming to boost Indian agriculture, the Government of India has set up a goal to double the farmers' income level by the year 2022. It is possible by formulating suitable action plan for development of location specific technologies, and timely transfer of such technologies to the farmers' fields. To fulfil the aim, a range of approaches and strategies need to be adopted starting from transformation of production-driven as well as market-driven factors and providing an enabling environment, which support farmers in all their endeavours. Current level of average income of an Indian farmer is about 
Rs. 6,430 per month (NSSO, 2012-13) with huge disparity among different regions, like farmers of Punjab earned highest income (Rs. 18,060) followed by those in Haryana (Rs. 14,440), Jammu \& Kashmir (Rs. 12,685) and Kerala (Rs. 11,890), whereas farmers of Bihar earn the least (Rs. 3,560) per month. Hence, instead of 'one solution fit for all', a mix of strategies will need to be embraced which not only enhance the income to double or nearly double, but discourage the level of disparity among different regions of India (ICARNRRI, 2017).

The results of gender researches reveal that despite the important role women play in agricultural production, they remain disadvantaged in numerous respects. On one hand, women have limited access to a wide range of agricultural inputs including seeds and fertilizers, technological resources, equipments, land and so forth. In addition, women often lack the capacity needed to deploy these resources. For example, women may have access to land but lack the capacity needed to deploy the resources as mentioned above. Illiteracy, neo-literacy and lack of scientific knowledge are the major impediments in their growth. Furthermore, many non-tangible assets, such as social capital, human capital, rights and decisionmaking power, are more difficult for women to access and exercise due to cultural barriers and male domination (ICAR-CIWA, 2015).

In this background, this study was taken up with the objectives of, profiling of income generating activities of farm families and identifying points of interventions; conducting micro level studies to identify gender concerns and technological gaps in doubling farm income; implementing technological modules for enhancing productivity and doubling income with emphasis on integrating gender roles and to study the impact of the interventions to develop a gender-sensitive model for doubling farmers' income.

\section{Materials and Methods}

The study was taken up in a cluster of 50 farm women from selected villages in Nimapara block of Puri district in Odisha during 20172020. Mixed methods research approach was followed for collecting qualitative and quantitative data using focussed group discussions, key-informant interviews, and indepth household interviews. Assessment of demographic profile, primary data collection on gendered contribution to family income, gendered scope of doubling family income and analysis of cropping pattern and other allied activities were carried out. Mapping the resource-base of the eco-system was done using PRA tools and interaction with local leaders and key informants. Analysis of income generating activities, income pattern and expenditure (cost of cultivation), and activity wise income generation by men and women were carried out through analysis of secondary/ census data/ micro level studies. Identification of gaps and prioritization of needs were done through stakeholder meetings, group interactions, field work and interview schedule based formal and informal surveys. Micro level studies were also conducted for identification of gaps and prioritization of needs, and developing an action plan. Implemented the need based modules for doubling the income of farm families through training, demonstrations, capacity building programmes, input support and advisory services. Modules were allotted to different farm families as per their resources and interests. Concurrent monitoring and impact assessment were also done.

The gender sensitive indicators followed for this study are summarized in the following table (Table 1.) 


\section{Results and Discussion}

Disparity in Farmers' Income among the States in India

There is large disparity existing in annual farm household income of different states (Fig. 1). To analyse the disparity, the states were divided into four Farmers' Income Zones (FIZ) as per their annual farm household income. The national average annual farm household income is Rs. $1,07,780 /$-. If the income of the farmers of various states is doubled from their present income, the disparity and gap of income will also be doubled in absolute terms. To address the problem, instead of doubling the farmers' income of every farmers' Income Zone equally, the focus should be increasing the farmers' income by different factors in different FIZs so that overall the countries average farmers' household income would be doubled but the disparity will be narrowed down. It is proposed that the income of farmers in FIZ1 may be increased by 1.5 times, whereas for FIZs 2, 3 and 4 the incomes may be increased by 2.0, 2.5 and 3.5 times, respectively to achieve overall doubling of famers' income at all India level without widening the gap in the annual farm household income among the Income Zones (Courtesy: Odisha State Document on DFI, 2022 (2017), ICAR-NRRI).

\section{Options for Improving Farmers' Income}

Farmers' income can be improved when productivity goes up, cost of production comes down, risk is reduced, post-harvest loss is minimized and commodities produced get a remunerative price. It should also improve income from allied activities to agriculture. The strategy should integrate these all. The following options are available for increasing farmers' income in rice-based systems (Pasupalak et al., 2018).

\section{Improving productivity and quality}

Providing quality seed and enhancing seed replacement ratio

Promoting high-yielding varieties and hybrids

Growing nutrient rich (CR Dhan 310 and 311) and aromatic rice (Basmati)

Increasing cropping intensity in rice-fallow areas

\section{Increasing input use efficiency}

Crop planning to identify areas where the crop can be grown with least input

Promoting water harvesting and microirrigation to achieve per drop-more crop

Using soil health card and site-specific crop management

Promoting farm mechanization and solar energy

\section{Reducing crop loss}

Adopting plant protection measures

Promoting resistant varieties and esurveillance

Crop insurance to mitigate risks at affordable cost

Weather services and forecasting system

\section{Diversification}

Dairy husbandry for small farmers

Promotion of intensive vegetable production

Promotion of ancillary activities like poultry, beekeeping and fisheries

Strengthening Organic Food Program

Market price realization and value addition

Community/co-operative farming with cropvalue chain

Use of the crop biomass to make products through small industry

Creation of a national farm market with 
information system for export and online selling

Agribusiness Incubation Centres to promote agri-preneurship

\section{Gender Sensitive Model for Doubling Farmers' Income by Addressing Gender Concerns and Technological Gaps}

The gender-sensitive model for doubling farmers' income was evolved as shown in Fig. 2.

The gender perspectives were integrated by way of assessment of gender concerns in accessing productive resources and extension services among the farm families, counselling and gender sensitization of the community, and promoting community organizations (knowledge groups of women). A team of experts analyzed the technological and developmental gaps and designed logical technological modules. The need based modules were implemented through training, demonstrations, capacity building programmes, input support and advisory services, promoting high yielding varieties and hybrids through 16 programmes covering the selected farm families during the period 2017-2020.

\section{Technological Interventions for DFI}

Promoting high yielding varieties and hybrids

Capacity building programmes- Training and demonstrations

Advisories on site-specific crop management/ allied activities

Soil test campaigns

Promoting drudgery reducing farm tools

Animal health camps

Development of knowledge and skill on maintaining farm log books (expenditure and income)

Development of knowledge and skill to reduce cost of cultivation/cost cutting
Development of knowledge and skill on waste reduction/waste recycling

Development of knowledge and skill to minimize post harvest losses

Development of knowledge and skill on primary processing/value addition

Awareness creation on market linkages

Regular interfaces and monitoring

Convergence of developmental agencies

Concurrent monitoring and impact assessment were done using participatory tools and interview schedule based surveys (baseline and endline surveys). The impact of the field level capacity building and technology transfer programmes, and the outputs realized are given in the following table (Table 2).

The impact of gender integration on family income and the cash in hand among farmwomen are given in Table 3 and Fig.3.

From Table 2 and Fig.3., it could be inferred that the technological interventions could result in the enhancement of annual farm income from Rs. 89,300/- to Rs. 1,51,200/(60\% enhancement), and cash in hand among farm women (mean annual savings) from Rs. $18,000 /$ - to Rs. $42,000 /$ - (43\% enhancement) between 2017-18 to 2019-20.

\section{Extension Strategies for Gender Mainstreaming and Improving Livelihood}

It is pertinent to build the capacity and ability of farmwomen to shoulder new challenges and increase their efficiency. Important extension strategies to improve women's access to productive resources for gender mainstreaming and improving livelihood learnt from the study are as follows;

Gender balanced extension system: Agricultural knowledge is transferred inefficiently from men to women and viceversa. Hence, there is need to increase number 
of women extension workers, leading to a gender balance in extension system which will enable women farmers will have easy access to agricultural information and technologies.

Mass media support: The access of farm women to mass media is limited due to number of reasons. But it has potential to carry messages to a large number of farm women. However, we should examine how different media support and extension model can contribute to the dissemination of farm information and technologies to the women.

Women friendly technologies: The scope of agricultural knowledge \& technologies for women farmers is increasing gradually. There are many technologies developed and standardized for agriculture by the National Agricultural Research and Extension System, but their potential for women and agriculture has not been adequately demonstrated. There is a dire need to harness the potential of science and technology by demonstrating their benefits, thus empowering women. Extending the women friendly tools and technological innovations will reduce the burden, and save time and energy of women.

Credit and technical support: Technical support should be provided to farm women which facilitates their multiple tasks. Credit facility should be given to women SHGs to increase income by way of developing microenterprises.

Capacity building of women: Different agricultural training programmes in different areas will largely improve the access to agricultural knowledge and information among farm women. Therefore, gender sensitive extension training materials should be developed.

Reorientation of extension and research system: Extension and research system should be reoriented and priorities should be given to women farmers.

Women farmer groups: There is need to organize the women farmers into groups in order to strengthen their way from subsistence cultivator to commercial cultivator. Extension workers can be trained to work more closely with women and organize them into groups.

Women friendly IFS model: Involvement of women in crop and livestock production varies according to the type of crop grown and livestock reared, and socio-economic conditions. There is need to develop scientifically designed, economically profitable and socially acceptable integrated farming systems models especially for women farmers having integration of women friendly farm enterprises.

\section{Promotion / support of marketing through} e-NAM and establishment of value chain.

To increase income of farmers, a range of strategies (economic, technological, infrastructural/information, political/policy and social) need to be adopted to transform the current production-driven to incomedriven farming system and reduce the disparity among farmers of different regions of India. A region and state-specific action plan is required to address the constraints of increasing farmers' income. 
Table.1 Gender sensitive indicators followed

\begin{tabular}{|c|c|c|}
\hline Types of Indicators & Indicators & $\begin{array}{l}\text { Methodology to measure the } \\
\text { indicator }\end{array}$ \\
\hline Input Indicators & $\begin{array}{l}\text { Resource base: existing access } \\
\text { to productive resources among } \\
\text { men and women } \\
\text { Allocation of resources to men } \\
\text { and women } \\
\text { Knowledge and skill } \\
\text { Socio-economic profile of men } \\
\text { and women } \\
\text { Action plan- technological } \\
\text { modules }\end{array}$ & $\begin{array}{l}\text { Agro-eco System Analysis-PRA } \\
\text { tools } \\
\text { Bench mark survey } \\
\text { Focussed group discussions, key- } \\
\text { informant interviews, and in-depth } \\
\text { household interviews } \\
\text { Scenario building on the basis of } \\
\text { existing technological gaps \& } \\
\text { prioritization of needs }\end{array}$ \\
\hline Output Indicators & $\begin{array}{l}\text { Number of beneficiaries } \\
\text { No. of knowledge groups } \\
\text { established } \\
\text { Enhanced access to productive } \\
\text { resources among men and } \\
\text { women } \\
\text { Increased productivity } \\
\text { Successful case studies/ } \\
\text { success stories }\end{array}$ & $\begin{array}{l}\text { Focussed group discussions, key- } \\
\text { informant interviews, and in-depth } \\
\text { household interviews } \\
\text { Bench mark and end line surveys } \\
\text { Documentation of successful cases }\end{array}$ \\
\hline Outcome indicators & $\begin{array}{l}\text { Gender-sensitive } \\
\text { sustainable model for doubling } \\
\text { the income of farm families } \\
\text { Enhanced farm income realized } \\
\text { Policy recommendations to } \\
\text { improve the farm women's } \\
\text { access to resources and } \\
\text { extension services for farm } \\
\text { women }\end{array}$ & $\begin{array}{l}\text { Participatory monitoring and } \\
\text { evaluation } \\
\text { Baseline and end line surveys. }\end{array}$ \\
\hline Impact Indicators & $\begin{array}{l}\text { Convergence of agencies } \\
\text { Enhanced socio-economic } \\
\text { status }\end{array}$ & $\begin{array}{l}\text { Stakeholders' interfaces } \\
\text { Participatory monitoring and } \\
\text { evaluation } \\
\text { Baseline and end line surveys }\end{array}$ \\
\hline
\end{tabular}


Table.2 Income enhancement through technological interventions

\begin{tabular}{|c|c|c|}
\hline \multirow[t]{2}{*}{ Technological Interventions... } & \multicolumn{2}{|c|}{ Yield/ Income } \\
\hline & $\begin{array}{l}\text { Before the } \\
\text { technological } \\
\text { interventions }\end{array}$ & $\begin{array}{l}\text { After the } \\
\text { technological } \\
\text { interventions }\end{array}$ \\
\hline $\begin{array}{l}\text { Varietal replacement in paddy } \\
\text { (Submergence tolerant varieties: Swarna } \\
\text { Sub-1; CR-1009 Sub-1) }\end{array}$ & $\begin{array}{l}13-15 \text { q/ac } \\
\text { (Rs.16,500) }\end{array}$ & $\begin{array}{c}22 \mathrm{q} / \mathrm{ac} \\
(\mathrm{Rs} .24,200)\end{array}$ \\
\hline $\begin{array}{l}\text { Cauliflower- varietal replacement and } \\
\text { improved methods (Var: NS60N (F1 Hyb); } \\
\text { Yield; 50q/ac; Invt: } 10,000 /-)\end{array}$ & Rs. $40,000 / \mathrm{ac}$ & Rs. $75,000 / a c$ \\
\hline $\begin{array}{l}\text { Improved methods of vegetable cultivation / } \\
\text { popularization of Arka varieties } \\
\text { (Var: Arka; Yield; } 70 \text { q/ ac; Investment: } \\
\text { 10,000/-) }\end{array}$ & Rs. $45,000 /$ ac & Rs. 70,000/ ac \\
\hline $\begin{array}{l}\text { Plantations- Banana, Papaya } \\
\text { (Var: Bantala, Grand Naine \& Red Lady; } \\
\text { Investment: } 4,000 /- \text { ) }\end{array}$ & Nil & Rs. $15,000 / 0.25 \mathrm{ac}$ \\
\hline Backyard poultry (Breed: Vanaraja) & Rs. 3000/ yr & Rs. $6000 / \mathrm{yr}$ \\
\hline Drudgery reduction- minor farm tools & - & $\begin{array}{l}\text { Increased work } \\
\text { efficiency }\end{array}$ \\
\hline Nutrition- Green leafy vegetables & - & Family nutrition \\
\hline $\begin{array}{l}\text { Mobilization of community for building } \\
\text { compost pits }\end{array}$ & - & $\begin{array}{l}\text { Waste reduction/ } \\
\text { recycling }\end{array}$ \\
\hline Annual family income & Rs. 89,300 & Rs. $1,51,200$ \\
\hline $\begin{array}{l}\text { Cash in hand among farm women } \\
\text { (mean annual savings) }\end{array}$ & Rs. 18,000 & Rs. 42,000 \\
\hline
\end{tabular}

Table.3 Income enhancement through gender integration

\begin{tabular}{|l|c|c|c|}
\hline $\begin{array}{l}\text { Income generating } \\
\text { activities }\end{array}$ & $\begin{array}{c}\text { Women's } \\
\text { contribution in } \\
\text { labour (\%) }\end{array}$ & $\begin{array}{c}\text { Women's } \\
\text { contribution in } \\
\text { financial decisions } \\
(\%)\end{array}$ & $\begin{array}{c}\text { Women's } \\
\text { contribution in } \\
\text { family income (\%) }\end{array}$ \\
\hline Crops & 33.00 & 40.00 & 30.00 \\
\hline Livestock & 68.00 & 60.00 & 65.00 \\
\hline Wage earning & Nil & Nil & Nil \\
\hline $\begin{array}{l}\text { Enterprises } \\
\text { (Mushroom) }\end{array}$ & 58.00 & 55.00 & 55.00 \\
\hline Services & Nil & Nil & Nil \\
\hline Others (if any) & Nil & Nil & Nil \\
\hline
\end{tabular}


Fig.1 Annual farm household income in different states of India

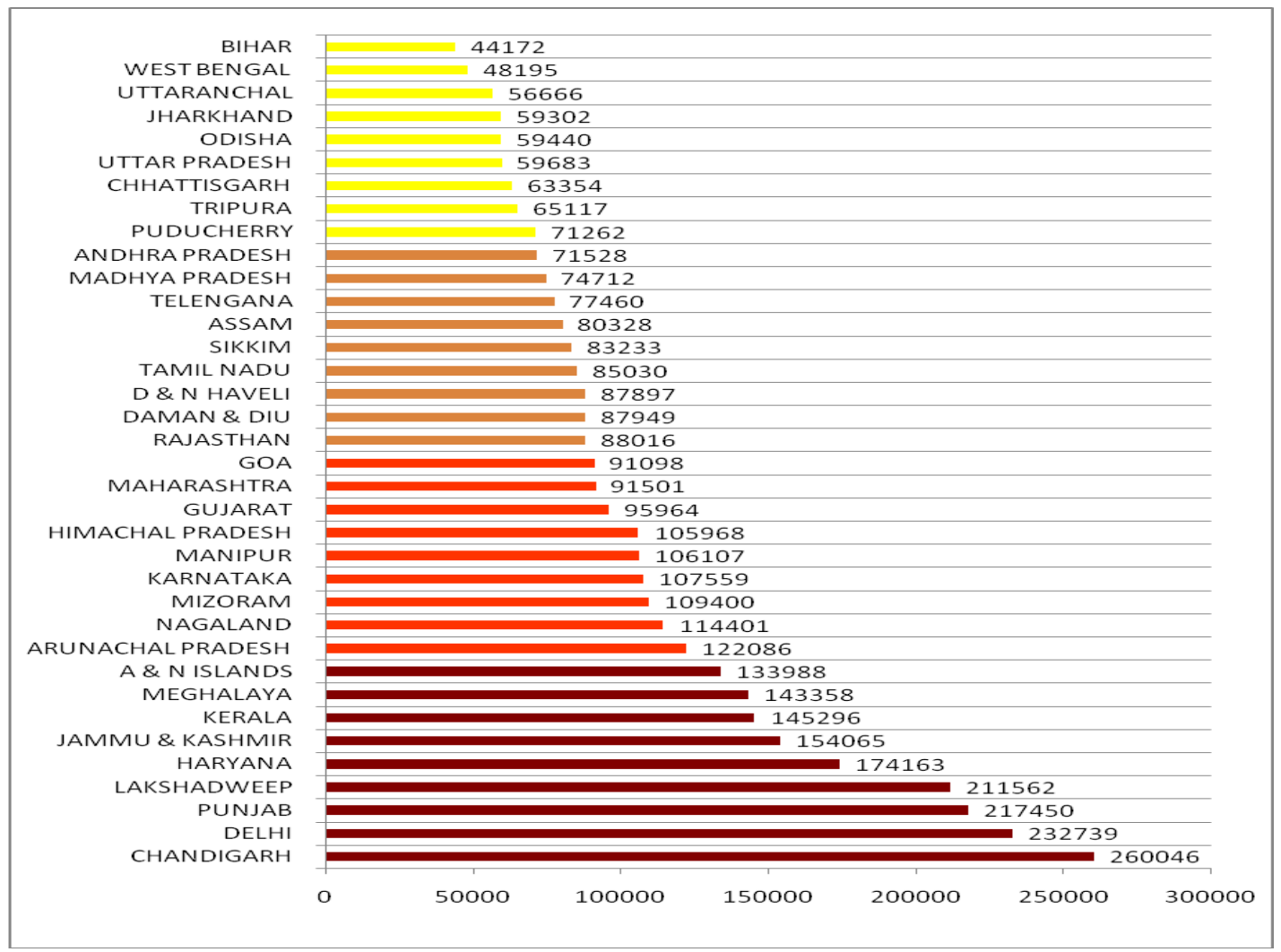

(Courtesy: Odisha State Document on DFI, 2022 (2017), ICAR-NRRI)

Fig.2 Gender-sensitive model for doubling farmers' income

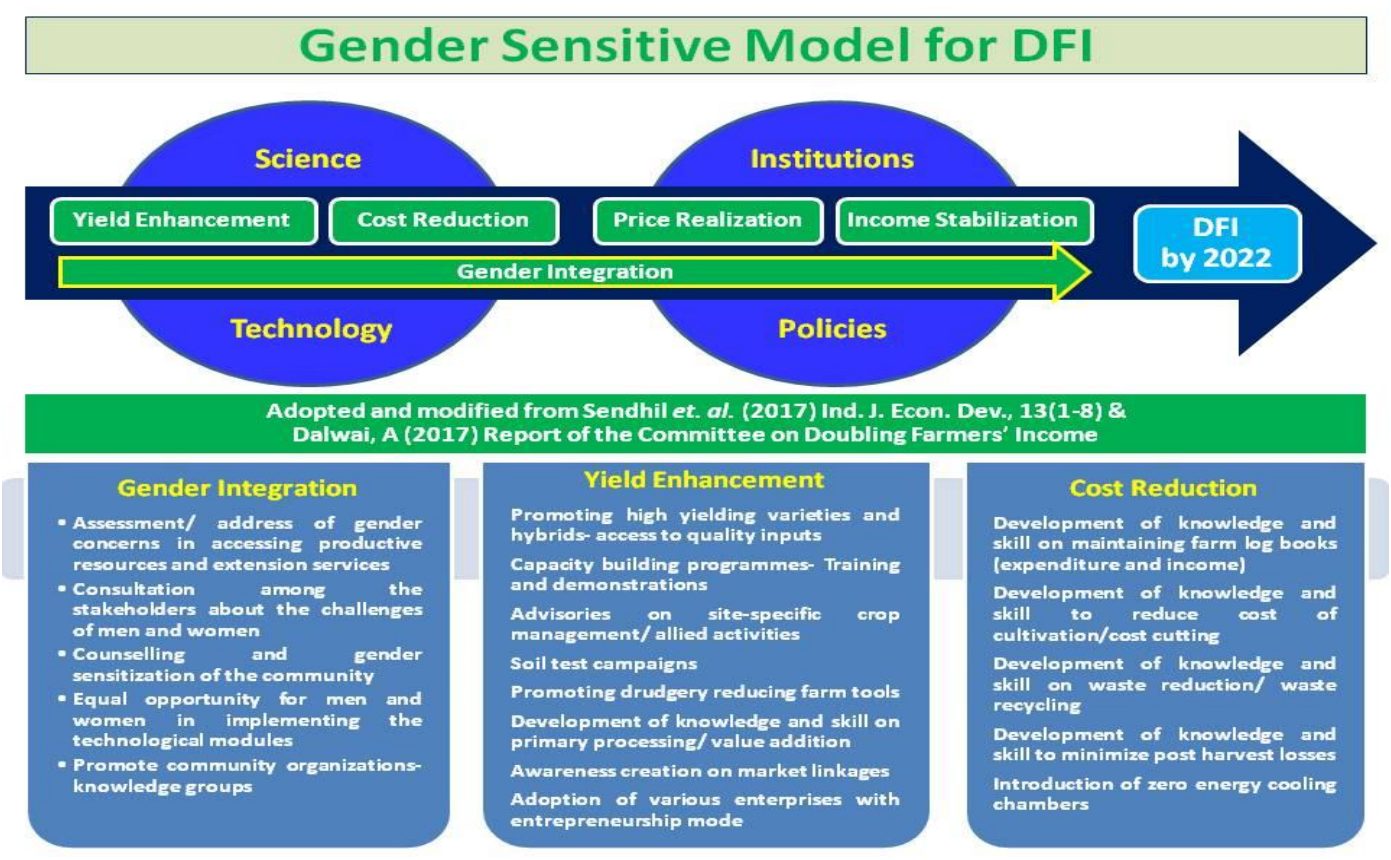


Fig.3 Impact of gender integration on family income/cash in hand among farm women

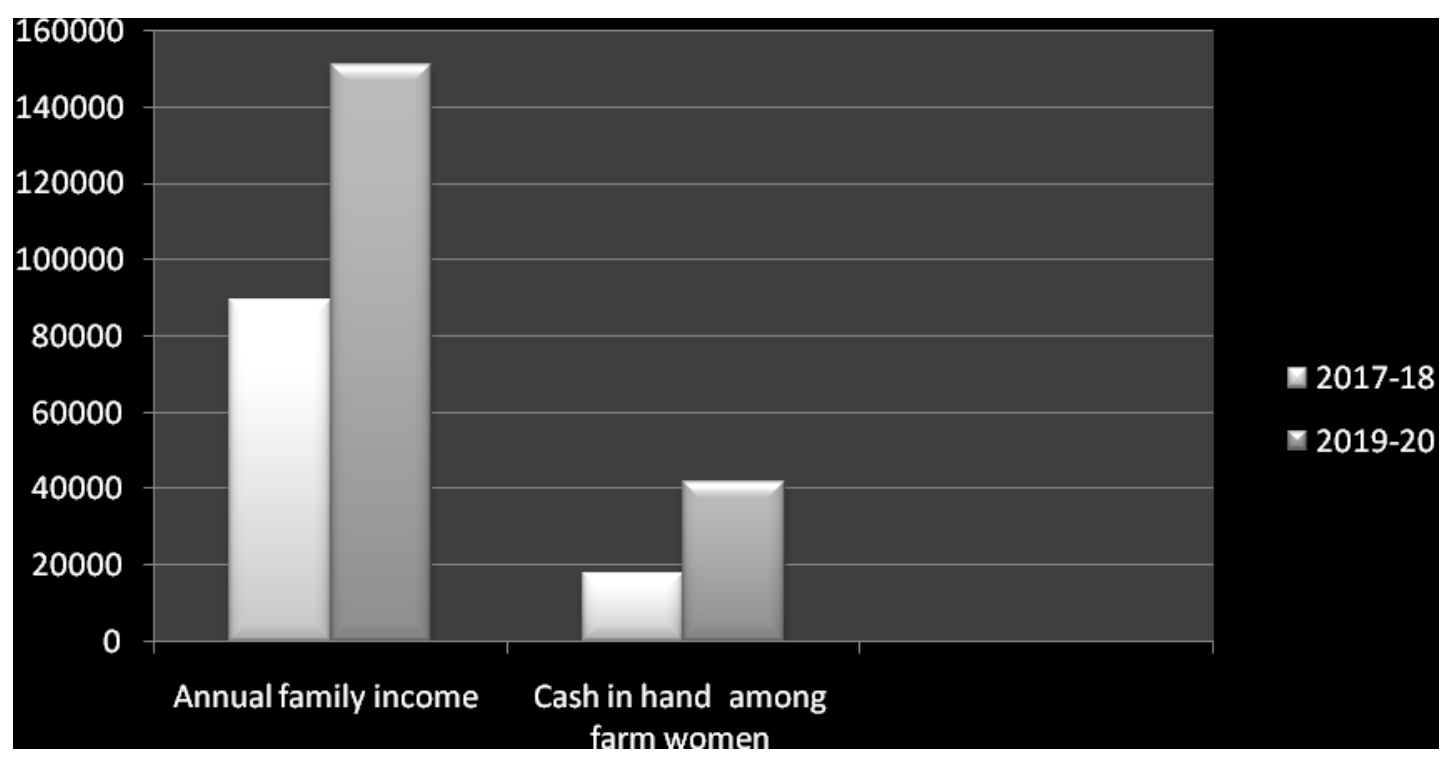

For gender mainstreaming the focus should be on

Recognising women's role as farmer/ agripreneur

Promoting agricultural education among farm women

Creation of well structured gender sensitive modules for effective transfer of technologies

Gender mainstreaming in govt. programmes $\&$ policies

Building resilience among farm women to cope with natural calamities and climate change

Create database on women's participation in agriculture

\section{References}

Dalwai, A. 2017. Report of the Committee on Doubling Farmers' Income, Committee on Doubling Farmers' Income, Department of Agriculture, Cooperation and Farmers' Welfare, Ministry of Agriculture \&
Farmers' Welfare., GOI, Vol. 14. p. 174. FAO. 2011. The state of food and agriculture: Women in agriculture. Closing the Gender Gap for Development, Rome: FAO.

ICAR-CIWA. 2015. Vision 2050, ICARCentral Institute for Women in Agriculture, Bhubaneswar. pp. 1-32.

ICAR-NRRI. 2017. Odisha State Document on Doubling Farmers Income by 2022 (Unpublished), ICAR-NRRI, Cuttack.

Pasupalak, S., Pathak, H., Roul. P.K., Kumar, G.A.K. and Mohapatra, M.R. 2018. Doubling farmers; Income by 2022: Strategy Document for Odisha, ICARNRRI, Cuttack. p.117.

Sendhil, R., Kumar, A., Singh, S., Chatrath, R. and Singh, G.P. 2017. Framework for doubling farmers income by 2022. Ind. J. Econ. Dev. 13: 1-8.

Sendhil, R., Ramasundaram, P. and Balaji, S.J. 2017. Transforming Indian agriculture: is doubling farmers income by 2022 in the realm of reality?. Current Science. 113 (5): 848-850. 


\section{How to cite this article:}

Charles Jeeva, J., S. K. Srivastava, Anil Kumar, Sabita Mishra, A. K. Panda, Jyoti Nayak, S. Tanuja, Ankita Sahu, B. C. Behera, M. Prusty and Subrat Kr. Das 2020. Doubling Farmers Income through Gender Specific Interventions. Int.J.Curr.Microbiol.App.Sci. 9(07): 15241533. doi: https://doi.org/10.20546/ijcmas.2020.907.176 